\title{
STRATEGI PENCEGAHAN KECURANGAN (FRAUD) DALAM PENGELOLAAN KEUANGAN PEMERINTAH MENGGUNAKAN ANALYTICAL HIERARCHY PROCESS
}

\author{
The Strategies for Fraud Prevention on Government Financial Management \\ with Analytical Hierarchy Process
}

\section{Novia Tri Kurniasari1 ${ }^{1}$ Anna Fariyanti², Nirwan Ristiyanto ${ }^{3}$}

\author{
1 Staf Pusat Penelitian dan Pengembangan Hutan. Kementerian Kehutanan. Email: \\ noviakurniasari87@yahoo.co.id \\ 2Staff Pengajar Departemen Agribisnis. Fakultas Ekonomi dan Manajemen. IPB. Email: \\ a_fariyanti@yahoo.com \\ ${ }^{3}$ Staff Pengajar Manajemen Pembangunan Daerah. Fakultas Ekonomi dan Manajemen. IPB Email: \\ nirwanristiyanto@yahoo.com
}

\begin{abstract}
Fraud phenomenon involves many actors from the government sector. Fraudulent practices in government has a negative impact on the economic and social sectors. Therefore, need for prevention effort to avoid state's material and non material losses. The objectives of this study were to formulate fraud prevention strategies by using Analytical Hierarchy Process. Sources of data used in this study were questionnaires and interviews to 5 expert respondent. Strategies for fraud prevention on government financial management: (1) improving the supervision and control system, (2) improving the organizational culture, (3) formulating anti fraud value in the organization, (4) implementing reward system and punisment firmly, (5) anti fraud socialization for employees, and (6) forming agent of change.
\end{abstract}

Key words: fraud prevention, internal control system, organizational culture, anti fraud value, Analytical Hierarchy Process

ABSTRACT

Fenomena kecurangan banyak melibatkan pelaku dari sektor pemerintahan. Praktik kecurangan di pemerintahan berdampak negatif di sektor ekonomi dan sosial. Oleh karena itu, perlu upaya pencegahan untuk menghindari kerugian negara material maupun non material. Tujuan penelitian ini adalah merumuskan strategi pencegahan fraud dalam pengelolaan keuangan menggunakan Analytical Hierarchy Process (AHP). Sumber data yang digunakan dalam penelitian ini adalah kuesioner dan wawancara kepada 5 responden yang dianggap ahli. Strategi pencegahan fraud dalam pengelolaan keuangan pemerintah adalah: (1) Perbaikan sistem pengawasan dan pengendalian, (2) meningkatkan kultur organisasi, (3) merumuskan nilai anti fraud, (4) menerapkan sistem reward dan punishment yang tegas, (5) sosialisasi anti fraud bagi pegawai, dan (6) membentuk agen perubahan.

Kata Kunci: Pencegahan Fraud, Sistem Pengendalian Intern, Budaya Organisasi, Nilai Anti Fraud, Proses Hirarki Analisis

\section{PENDAHULUAN}

Fraud masih menjadi isu fenomenal dan menarik untuk dibahas dengan kasus-kasus yang kini tengah berkembang dalam masyarakat. Association of Certified Fraud Examiners menggolongkan fraud dalam tiga jenis, yaitu kecurangan dalam laporan keuangan, penyalahgunaan aset dan korupsi (Surjandari dan Martaningtyas 2015). Salah satu jenis fraud yang paling sering terjadi di sektor pemerintahan yaitu berkaitan dengan praktik korupsi. Korupsi berasal dari bahasa latin, Corruptio-Corrumpere yang artinya busuk, rusak, menggoyahkan, 
memutarbalik atau menyogok (Permana et al. 2017).

Indonesia merupakan salah satu negara dengan tingkat korupsi yang tinggi. Data yang dihimpun oleh Indonesian Corruption Watch menunjukkan bahwa selama tahun 2016, terdapat 482 kasus korupsi dengan total kerugian negara sebesar Rp 1,47 Triliun (Indonesian Corruption Watch 2017). Transparansi Internasional dalam surveynya tahun 2016 juga menunjukkan bahwa Indonesia menempati peringkat 90 dari 176 negara yang diukur tingkat korupsinya dengan skor 37 (Transparency International 2016).

Reformasi dibidang keuangan negara telah dilaksanakan melalui paket Undang-Undang yang terdiri dari Undang-Undang Nomor 17 Tahun 2003 tentang Keuangan Negara, Undangundang Nomor 1 Tahun 2004 tentang Perbendaharaan Negara dan Undangundang Nomor 15 Tahun 2004 tentang Pemeriksaan Pengelolaan dan Tanggungjawab Keuangan Negara. Ketiganya merupakan landasan dan pedoman agar keuangan negara dapat dikelola secara tertib, ekonomis, efisien, efektif, transparan dan bertanggung jawab dengan memperhatikan rasa keadilan dan kepatutan. Sejalan dengan tujuan tersebut, Undang-Undang nomor 28 tahun 2009 mengamanatkan untuk mewujudkan penyelenggaraan negara yang bebas dan bersih dari korupsi, kolusi dan nepotisme.

Banyaknya aturan tersebut diterbitkan sebagai upaya untuk menekan tingginya kasus kecurangan di Indonesia, namun ternyata belum bisa mengurangi jumlah kasus yang terjadi. Bahkan kecurangan yang melibatkan aparat pemerintah cenderung mengalami peningkatan. Data Komisi Pemberantasan Korupsi menunjukkan dari tahun 2004 sampai 2016, sebanyak 382 dari 616 40 pelaku tindak korupsi berdasarkan jabatan/profesi merupakan aparat pemerintah (Komisi Pemberantasan Korupsi 2017).

Pemerintah sebagai pengemban amanat dari rakyat mempunyai kewajiban untuk melaksanakan tugasnya secara efektif dan efisien, salah satunya adalah mengelola keuangan negara dengan baik dan accountable. Namun, pada pelaksanaannya banyak praktik kecurangan yang berdampak negatif pada sektor ekonomi maupun sosial (Lediastuti dan Subandijo 2014). Salah satu indikator terjadinya permasalahan dalam pengelolaan keuangan instansi pemerintah juga dapat dilihat dari hasil pemeriksaan Badan Pemeriksa Keuangan terhadap laporan keuangan.

Kecurangan dapat terjadi di instansi pemerintah manapun termasuk Badan X1. Pemeriksaan BPK atas laporan keuangan Badan X1 dari tahun 20132015 menemukan adanya kelemahan dalam sistem pengendalian intern. Temuan tersebut merupakan indikasi bahwa dalam pengelolaan keuangan Badan X1 belum menyajikan informasi keuangan yang handal dan masih rawan terhadap kecurangan, sehingga diperlukan upaya pencegahan. Upaya pencegahan fraud lebih efektif untuk dilakukan dibandingkan dengan upaya represif, antara lain menghindari kerugian negara yang lebih besar, serta rusaknya nama baik institusi dan individu. Selain itu, melakukan pencegahan dari awal akan lebih murah dan lebih efektif daripada mendeteksi setelah terjadinya fraud (Abdullahi 2015).

Analytical Hierarcy Process (AHP) merupakan alat analisis yang digunakan untuk membantu para pembuat keputusan untuk mengidentifikasikan dan sekaligus membuat prioritas berdasarkan tujuan yang ingin dicapai, pengetahuan yang dimiliki, dan pengalaman yang mereka miliki untuk masing-masing masalah yang dihadapi (Saaty 1993). Model AHP menggunakan persepsi seseorang yang ahli (expert) sebagai input utamanya, 
sehingga diharapkan strategi yang dirumuskan dapat benar-benar sesuai dengan yang dibutuhkan oleh instansi pemerintah. Berdasarkan hal tersebut, tujuan penelitian ini adalah merumuskan strategi untuk mencegah terjadinya kecurangan (fraud) dalam pengelolaan keuangan pemerintah menggunakan metode Analytical Hierarchy Process.

\section{METODOLOGI}

Penelitian ini menggunakan data primer melalui wawancara terstruktur dan pengisian kuesioner AHP kepada 5 responden yang dianggap ahli (expert) dan berkompeten dalam pengelolaan keuangan. Responden berasal dari Sekretariat Badan X1, Inspektorat Jenderal Kementerian $\mathrm{X}$, Badan Pemeriksa Keuangan dan Pembangunan (BPKP) dan Badan Pemeriksa Keuangan (BPK) serta akademisi. Pengumpulan data dilakukan pada bulan Mei 2017.

Penelitian ini dalam
memformulasikan strategi menggunakan Analytical Hierarcy Process (AHP) dengan bantuan aplikasi Expert Choice 11 dalam mengolah data. Metode AHP dipilih untuk memformulasikan strategi pencegahan fraud dalam pengelolaan keuangan pemerintah karena metode AHP mudah dalam menjelaskan proses pengambilan keputusan serta dapat digambarkan secara grafis. Selain itu, kelebihan model AHP dibandingkan model pengambilan keputusan lainnya terletak pada kemampuan AHP untuk memecahkan masalah yang multiobjectives dan multicriterias (Saaty 1993).
Menurut Saaty (1993) prinsip dasar AHP ada tiga, yaitu:

1. Menyusun Hirarki

Penyusunan hirarki dilakukan dengan cara mengidentifikasi pengetahuan atau informasi yang sedang diamati. Penyusunan tersebut dimulai dari permasalahan yang kompleks dan diuraikan menjadi elemen pokoknya. Elemen pokok ini diuraikan lagi ke dalam bagian-bagian yang lebih detail dan seterusnya. Hirarki prioritas strategi dalam penelitian ini disusun berdasarkan studi literatur dan wawancara dengan pejabat terkait. Struktur hirarki terdiri atas lima level, yaitu level 1 fokus, level 2 faktor, level 3 aktor, level 4 kendala dan level 5 strategi. Tujuan akhir dari perumusan strategi menggunakan analisis AHP adalah memilih prioritas strategi yang paling baik.

2. Menetapkan Prioritas

Langkah pertama yang dilakukan dalam menetapkan prioritas elemen pengambilan keputusan adalah dengan membuat perbandingan berpasangan (pairwise comparisons). Elemen-elemen tersebut dibandingkan berpasangan terhadap kriteria yang telah ditentukan. Untuk perbandingan berpasangan ini digunakan bentuk matriks. Dalam memulai perbandingan berpasangan ini, dimulai pada puncak hirarki untuk memilih kriteria atau sifat yang akan digunakan untuk melakukan perbandingan yang pertama (focus). Kemudian membandingkan elemenelemen ditingkat bawahnya sesuai jumlah dalam matrik. Contoh matrik perbandingan berpasangan dapat dilihat pada Tabel 1.

Tabel 1 Matrik untuk perbandingan berpasangan

\begin{tabular}{lccc}
\hline \multicolumn{1}{c}{ Fokus } & Efektivitas SPI & Budaya Organisasi & Moralitas Individu \\
\hline Efektivitas SPI & 1 & & \\
\hline Budaya Organisasi & & 1 & 1 \\
\hline Moralitas Individu & & & \\
\hline
\end{tabular}


Langkah berikutnya untuk mengisi matriks perbandingan berpasangan tersebut adalah mengisi berdasarkan skala nilai dengan angka antara 1 sampai 9. Nilai dan definisi nilai 1 sampai 9 dari skala perbandingan Saaty.

\section{Konsistensi Logis}

Langkah terakhir yang dilakukan dalam proses hirarki analitik adalah dengan memperhitungkan konsistensi logis, yaitu semua elemen dikelompokkan secara logis dan diperingatkan secara konsisten sesuai dengan kriteria yang logis. Proses hirarki analitik mengukur konsistensi menyeluruh dari berbagai pertimbangan melalui suatu rasio konsistensi. Nilai konsistensi yang dapat diterima adalah $\leq$ 0,1 karena jika nilai konsistensi lebih dari $10 \%$ artinya pertimbangan mungkin agak acak dan perlu diperbaiki (Saaty 1993).

\section{HASIL DAN PEMBAHASAN}

\section{Hasil Analisis dengan Analytical Hierarchy Process}

Perumusan strategi pencegahan fraud dalam pengelolaan keuangan Badan X1 menggunakan metode analitycal hierarchy process (AHP) sehingga prioritas yang dihasilkan akan bersifat konsisten dengan teori, logis dan transparan. Struktur AHP yang digunakan dalam penelitian ini terdiri dari 5 (lima) level, yaitu fokus, faktor, aktor, kendala dan strategi. Faktor-faktor yang digunakan dalam penyusunan hirarki adalah faktor yang berpengaruh terhadap fraud dalam pengelolaan keuangan, yaitu efektivitas sistem pengendalian intern, budaya etis organisasi dan moralitas individu.

Aktor-aktor yang digunakan dalam penyusunan hirarki adalah aktor yang memiliki kewenangan untuk mengendalikan faktor pendorong terjadinya fraud yaitu eselon II, auditor internal dan auditor eksternal. Kendalakendala yang menjadi skala prioritas dalam penyusunan hirarki adalah kendala yang dianggap dapat mempengaruhi aktor dalam upaya mencegah terjadinya fraud. Kendala-kendala tersebut adalah aspek individu, aspek organisasi, dan aspek peraturan

Level terakhir dalam penyusunan strategi adalah alternatif-alternatif strategi yang dipilih untuk mencegah terjadinya fraud dalam pengelolaan keuangan di Badan X1. Hasil perumusan strategi dengan AHP sesuai dengan hirarki dan urutan prioritas masing-masing level disajikan pada Gambar 1.

Tingkat peranan antar unsur pada setiap level dengan level di atasnya adalah sebagai berikut:

\section{Tingkat Peranan Faktor dalam Pencegahan Fraud dalam Pengelolaan Keuangan Badan X1}

Dari hasil pengolahan dengan metode AHP, perbandingan antar unsur "Faktor" Strategi Pencegahan Fraud dalam Pengelolaan Keuangan Badan X1, yaitu prioritas pertama sistem pengendalian intern dengan nilai 0,503 . Sistem pengendalian intern dinilai sebagai prioritas pertama karena dengan adanya sistem yang efektif akan menghilangkan adanya peluang bagi pegawai untuk melakukan fraud. Rae dan Subramaniam (2008) menemukan bahwa kualitas pengendalian internal dapat menekan terjadinya fraud karyawan. Jika kualitas sistem pengendalian intern buruk, maka bisa menjadi kesempatan bagi karyawan untuk melakukan kecurangan. Semakin efektif pengendalian internal di instansi pemerintah, semakin rendah tingkat kecurangan (Permana et al. 2017).

Prioritas selanjutnya adalah budaya etis organisasi dengan nilai 0,313 . Budaya organisasi merupakan nilai-nilai yang dikembangkan dalam organisasi sebagai pedoman dalam berperilaku. Budaya organisasi dapat mencegah perilaku kecurangan di organisasi (Wicaksono dan Urumsyah 2016). Budaya organisasi memiliki peran yang 
sangat penting didalam terbentuknya karakter anggota organisasi tersebut. Suatu organisasi yang memiliki budaya etis tinggi akan menekan anggotanya untuk tidak melakukan perbuatan yang menyimpang.

Prioritas terakhir adalah moralitas individu dengan nilai 0,184 . Salah satu penyebab kecurangan adalah kepribadian yang menggerogoti integritas seseorang. Subagio (2016) menyatakan bahwa akar masalah terjadinya kecurangan adalah kurangnya integritas aparatur negara, dimana dalam integritas terkandung kualitas moral dan sikap yang jujur, bijak, adil untuk melakukan hal yang benar dalam segala situasi. Semakin tinggi level moral individu, semakin ia berusaha untuk menghindarkan diri dari kecenderungan melakukan kecurangan yang dapat merugikan banyak pihak (Puspasari dan Suwardi 2012). Oleh sebab itu untuk mencegah fraud dalam suatu organisasi perlu mendorong penguatan moral individu.

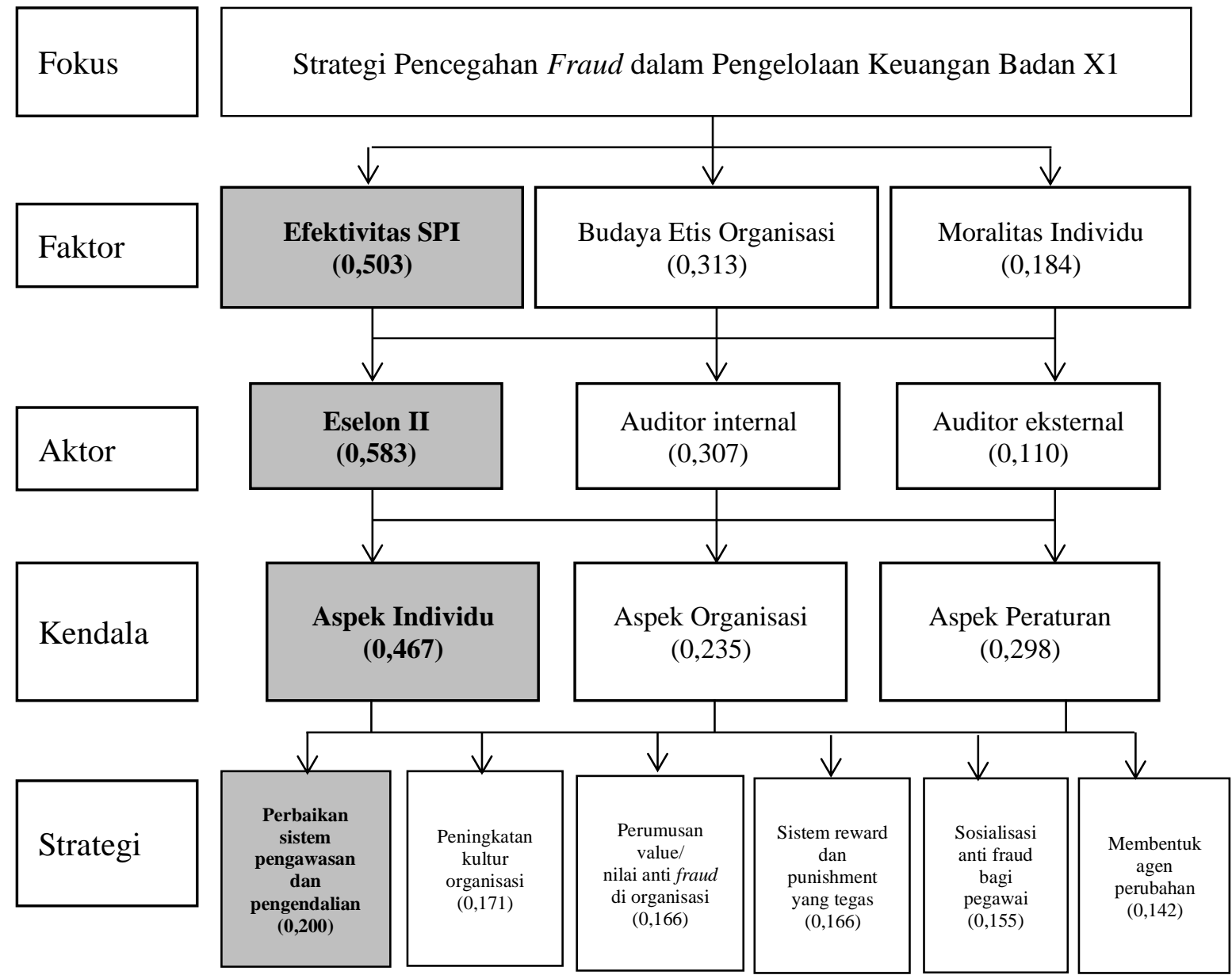

Gambar 1 Struktur dan Nilai Bobot Hirarki AHP

2. Tingkat Peranan Aktor dalam Pencegahan Fraud dalam Pengelolaan Keuangan Badan X1

Dari hasil pengolahan dengan metode AHP, perbandingan antar unsur "Aktor" Strategi Pencegahan Fraud dalam Pengelolaan Keuangan Badan X1, yaitu prioritas pertama Eselon II dengan nilai 0,583 . Eselon II dinilai memiliki peluang dan prioritas yang paling besar karena secara langsung setiap kegiatan dalam lingkup Badan X1 merupakan hasil dari kebijakan dan keputusan yang diambil oleh para Eselon II. Selain itu pihak manajemen dalam hal ini Eselon II juga mempunyai peran penting dalam 
menentukan lingkungan etis organisasi dengan menunjukkan teladan yang layak sehingga bisa menjadi panutan bagi pegawai di bawahnya. Manajemen juga harus menyediakan mekanisme bagi pegawai untuk melaporkan jika terjadi perilaku tidak etis, fraud, dan penyimpangan atas kebijakan etis atau aturan perilaku dalam organisasi.

Aktor auditor internal diprioritaskan pada urutan kedua dengan nilai 0,307. Kegiatan pengawasan internal pada Badan X1 dilakukan oleh Inspektorat Jenderal Kementerian $\mathrm{X}$. Peraturan Menteri Pendayagunaan Aparatur Negara dan Reformasi Birokrasi Nomor 19 tahun 2009 tentang Pedoman Kendali Mutu aparat pengawas intern pemerintah, mendefinisikan Pengawasan intern sebagai seluruh proses kegiatan audit, reviu, evaluasi, pemantauan, dan kegiatan pengawasan lain terhadap penyelenggaraan tugas dan fungsi organisasi dalam rangka memberikan keyakinan yang memadai bahwa kegiatan telah dilaksanakan sesuai dengan tolok ukur yang telah ditetapkan secara efektif dan efisien untuk kepentingan pimpinan dalam mewujudkan tata kelola/kepemerintahan yang baik.

Peran tersebut, diperkuat lagi dengan Peraturan Pemerintah Nomor 60 tahun 2008 tentang Sistem Pengendalian Internal Instansi Pemerintah (SPIP) pasal 48 yang menyatakan bahwa Aparat pengawasan intern pemerintah melakukan pengawasan intern melalui: audit, reviu, evaluasi, pemantauan, dan kegiatan pengawasan lainnya. Dimana fungsi pengawasan yang dilakukan APIP sampai dengan saat ini dilaksanakan melalui peran pemeriksaan (watchdog), peran konsultan (consultant) dan peran katalisator dan pendampingan manajemen (catalyst) .

Prioritas terakhir adalah auditor eksternal dengan nilai 0,110. Badan 44 Pemeriksa Keuangan (BPK) berperan dalam kegiatan pengawasan eksternal pada pemerintah. Berdasarkan Pasal 6
UU No. 15 Tahun 2006, BPK memiliki tugas memeriksa pengelolaan dan tanggung jawab keuangan negara yang dilakukan oleh Pemerintah Pusat, Pemerintah Daerah, Lembaga Negara lainnya, Bank Indonesia, Badan Usaha Milik Negara, Badan Layanan Umum, Badan Usaha Milik Daerah, dan lembaga atau badan lain yang mengelola keuangan negara.

\section{Tingkat Peranan Kendala dalam Pencegahan Fraud dalam Pengelolaan Keuangan Badan X1}

Perbandingan antar elemen "Kendala" yang menempati urutan pertama yaitu aspek individu dengan nilai 0,467. Kendala aspek individu yaitu kendala yang berasal dari dalam diri atau di bawah kendali individu tersebut, misalnya keterbatasan sumber daya manusia (kurang kompeten dan tidak memahami peraturan), sikap tidak peduli, menganggap tindakan curang yang dilakukan adalah hal yang lumrah, atau tidak berani melaporkan perilaku dan kejadian kecurangan yang terjadi di lingkungan kerjanya.

Prioritas kedua menurut responden adalah aspek peraturan dengan nilai 0,298. Kendala peraturan yaitu kualitas peraturan yang kurang memadai, penjatuhan sanksi yang terlalu ringan, penerapan sanksi tidak konsisten dan pandang bulu, serta lemahnya bidang evaluasi dan revisi peraturan. Prioritas terakhir menurut responden adalah aspek organisasi dengan nilai 0,235 . Kendala aspek organisasi yaitu tidak adanya teladan dan komitmen dari pimpinan sehingga pimpinan belum menjadi role model yang baik bagi pegawai dibawahnya dalam upaya pencegahan fraud.

\section{Tingkat Peranan Strategi dalam Pencegahan Fraud dalam Pengelolaan Keuangan Badan X1}

Perbandingan antar elemen "Strategi" yang menempati prioritas 
pertama untuk mencegah terjadinya fraud dalam pengelolaan keuangan yaitu melakukan perbaikan sistem pengawasan dan pengendalian $(0,200)$, prioritas kedua adalah peningkatan kultur organisasi $(0,171)$, prioritas ketiga adalah perumusan value/nilai anti fraud di organisasi $(0,166)$ dan penerapan sistem reward dan punisment yang tegas $(0,166)$, prioritas selanjutnya adalah sosialisasi anti fraud bagi pegawai (0.155) dan terakhir pembentukan agent of change/agen perubahan (0.142).

Responden menilai bahwa strategi yang perlu dijadikan prioritas utama adalah perbaikan sistem pengawasan dan pengendalian. Dengan adanya sistem yang baik yang diterapkan di lingkup Badan X1 akan mampu meminimalkan dan mengeliminasi motivasi pegawai dan kesempatan untuk melakukan fraud.

\section{Implementasi Kebijakan}

\section{Perbaikan Sistem Pengawasan dan Pengendalian}

Konsep untuk meningkatkan pengendalian organisasi menurut The Institute of Internal Auditor (2013) berkaitan dengan pembagian peran dan tanggung jawab penerapan manajemen risiko dan pengendalian internal menjadi 3 (tiga) lini dalam organisasi. Manajemen operasional menjadi lini pertahanan pertama yang bertanggung jawab penuh untuk menjalankan seluruh kebijakan organisasi dengan menjalankan pengendalian intern secara terus menerus dalam seluruh tahapan kegiatan. Lini pertahanan kedua bertugas untuk memantau dan menjaga kepatuhan pelaksanaan pengendalian intern serta memberi masukan pada lini pertama. Lini pertahanan ketiga adalah aparat pengawas intern pemerintah (APIP) atau auditor internal yang bertugas untuk memberikan penilaian dan melakukan pemantauan pengendalian intern secara obyektif.

Pertama, kegiatan pengendalian intern yang dilakukan oleh pihak manajemen operasional melalui pengawasan melekat, yaitu pemantauan terhadap kegiatan yang dilakukan oleh atasan terhadap staf di lingkungan unit kerjanya. Pengawasan melekat yang dilakukan antara lain adanya pelaksanaan manajemen risiko, penggunaan sistem informasi manajemen untuk seluruh kegiatan, uji petik pembelian barang/jasa dan rekonsiliasi antara verifikator keuangan dan pelaksana kegiatan.

Kedua, membentuk unit pengendalian internal untuk membantu manajemen operasional sebagai unit terdekat guna melakukan pemantauan pelaksanaan pengendalian intern. Pemantauan oleh unit pengendalian internal akan mendorong penyelesaian masalah secara lebih cepat dan terbuka. Unit pengendalian internal juga berperan sebagai petugas etika untuk membantu pegawai menyelesaikan dilema etis yang dihadapi dan untuk melaporkan dugaan fraud yang melibatkan manajemen.

Terakhir, optimalisasi auditor internal dapat dilakukan dengan mengoptimalkan perannya terkait dengan kegiatan pembinaan SPIP bersama dengan BPKP. Selain itu auditor internal juga melaksanakan peran pembinaannya dengan dilibatkan dalam kegiatan pembinaan terhadap pegawai terkait kesadaran terhadap fraud melalui sosialisasi, maupun pendidikan dan pelatihan.

\section{Peningkatan Kultur Organisasi}

Peningkatan kultur organisasi yang selaras dengan program anti fraud yang dapat dilakukan di lingkup Badan X1 yaitu:

a. Menunjukkan teladan pimpinan

Perilaku bawahan merupakan refleksi dari perilaku pemimpinnya. Jika pemimpin mempromosikan perilaku yang baik maka bawahan akan meniru, begitu juga sebaliknya (Wicaksono dan Urumsah 2016). Komitmen pimpinan diperlukan sebagai upaya dalam mencegah fraud. Komitmen dapat 
diekspresikan dalam bentuk keteladanan yang di dukung dengan penyediaan sumber daya yang memadai baik SDM, dana, maupun sarana dan prasarana (Wiranta 2015).

b. Menciptakan lingkungan kerja yang positif

Seseorang akan cenderung menyesuaikan diri dengan apa yang telah menjadi kebiasaan dalam lingkungan kerjanya. Lingkungan kerja yang baik akan meningkatkan kreativitas, perilaku etis dan kinerja yang akan menjadi penghalang terjadinya fraud (Wicaksono dan Urumsyah 2016). Upaya untuk menciptakan lingkungan kerja yang positif antara lain target penyerapan anggaran yang realistis, pembagian wewenang dan tanggung jawab yang jelas, komunikasi yang baik antar pegawai dan atasan, dan perilaku sederhana dan bersahaja.

\section{Perumusan Value/Nilai Anti Fraud dalam Organisasi}

Sistem nilai ini diwujudkan dalam suatu aturan perilaku (code of conduct) yang merefleksikan nilai utama dari organisasi. Aturan perilaku memberi pedoman pada pegawai dalam bekerja terkait peran dan tanggungjawabnya dan mengambil keputusan yang benar terkait dengan dilema etis yang dialami dalam pekerjaannya. Salah satu nilai yang dapat digunakan sebagai pedoman untuk mencegah terjadinya fraud adalah nilai integritas. Menurut Subagio (2016), integritas memainkan peran penting dalam mencegah terjadinya kecurangan dalam birokrasi di Indonesia. Dalam integritas terkandung kualitas moral dan sikap yang baik agar seseorang dapat melakukan hal yang benar di segala situasi. Oleh karena itu penguatan integritas perlu terus didorong dalam lingkup Badan X1, antara lain melalui penandatangan pakta integritas bagi seluruh pegawai setiap tahun yang berisi indikator nilai integritas.

\section{Menerapkan Sistem Reward dan} Punishment yang Tegas

Sistem pengenaan reward maupun punishment sama-sama dibutuhkan untuk merangsang karyawan agar meningkatkan kualitas kerjanya. Reward diterapkan untuk memotivasi karyawan akan lebih bekerja maksimal dalam menjalankan tanggung jawab. Sedangkan punishment dikenakan terhadap karyawan yang melakukan kesalahan dan pelanggaran agar termotivasi untuk menghentikan perilaku menyimpang dan mengarahkan pada perilaku positif (Suherman 2017).

Selain reward berupa tunjangan kinerja, reward yang dapat diberikan kepada pegawai yaitu memberikan kesempatan untuk meningkatkan kemampuan sesuai bidang keahlian melalui diklat, promosi, dan melanjutkan pendidikan. Pemberian sanksi yang tegas juga harus dilakukan atas pelanggaran pegawai berdasar Peraturan Pemerintah Republik Indonesia Nomor 53 Tahun 2010 tentang Disiplin Pegawai Negeri Sipil dan pemotongan tunjangan kinerja berdasarkan Peraturan Tentang Tata Cara Pemberian Tunjangan Kinerja bagi Pegawai di Lingkungan Kementerian X.

\section{Sosialisasi/Pendidikan Anti Fraud bagi Pegawai}

Sosialisasi dan pendidikan anti fraud bertujuan untuk memperkuat setiap individu dalam mengambil keputusan yang etis dan berintegritas, serta menciptakan budaya zero tolerance terhadap fraud. Sosialisasi anti fraud bagi pegawai tidak hanya dilakukan dalam bentuk pendidikan dan pelatihan, namun juga melalui keteladanan dari pimpinan (Wiranta 2015). Pendidikan dan pelatihan terkait fraud dapat dilakukan pada saat penerimaan pegawai baru (induction training) dan harus terus dilakukan secara berkala setelah menjadi pegawai.

Seminar dan pelatihan etis digunakan untuk memperkuat nilai, 
tuntunan organisasi, menjelaskan praktik yang diperbolehkan dan yang tidak, serta menangani dilema etika yang mungkin muncul. Pelatihan etis merupakan alat untuk memahami dan mendalami arti etos, nilai-nilai, norma, etika, intergritas, dan standar perilaku yang ditetapkan dalam aturan perilaku dalam organisasi (codes of conduct).

Pendidikan anti fraud melalui promosi anti fraud dapat terus menerus dilakukan untuk meningkatkan kesadaran akan risiko fraud. Pendidikan anti fraud dapat melalui media cetak maupun elektronik di lingkungan kantor. Selain komunikasi tidak langsung, pendidikan anti fraud juga dapat dilakukan melalui seruan anti fraud dalam setiap kesempatan kepada seluruh pegawai, misalnya dalam rapat dan upacara.

\section{Membentuk Agen Perubahan (Agent of Change)}

Upaya untuk melakukan pencegahan fraud selain unsur keteladanan yang nyata dari pimpinan juga membutuhkan perubahan diri individu anggota organisasi. Untuk mempercepat perubahan kepada seluruh pegawai, sangat diperlukan beberapa individu yang bisa menjadi penggerak utama dalam perubahan sekaligus menjadi bisa menjadi role model bagi pegawai lain dalam berperilaku sesuai dengan nilai-nilai yang dianut oleh organisasi. Dengan dibentuknya agen perubahan diharapkan terjadi peningkatan integritas seluruh individu anggota organisasi, sehingga dapat mendorong terwujudnya penyelenggaraan pemerintah yang bebas fraud.

\section{SIMPULAN}

Berdasarkan hasil analisis yang dilakukan pada penelitian ini dapat disimpulkan bahwa: Faktor yang menjadi prioritas pertama adalah sistem pengendalian intern dengan nilai 0,503. Aktor yang menjadi prioritas pertama adalah Eselon II dengan nilai 0,583. Kendala yang menjadi prioritas pertama adalah aspek individu dengan nilai 0,467. Strategi yang menjadi prioritas pertama dalam upaya pencegahan fraud dalam pengelolaan keuangan Badan X1 yaitu melakukan perbaikan sistem pengawasan dan pengendalian $(0,200)$, prioritas kedua adalah peningkatan kultur organisasi $(0,171)$, prioritas ketiga adalah perumusan value/nilai anti fraud di organisasi $(0,166)$ dan penerapan sistem reward dan punisment yang tegas $(0,166)$, prioritas selanjutnya adalah sosialisasi anti fraud bagi pegawai $(0,155)$ dan terakhir pembentukan agent of change/agen perubahan $(0,142)$.

\section{DAFTAR PUSTAKA}

Abdullahi R., N. Mansor., dan MS. Nuhu. 2015. Fraud Triangle Theory and Fraud Diamond Theory. Understanding the Convergent and Divergent For Future Research. International Journal of Academic Research in Accounting, Finance and Management Sciences Vol 5 (4): 30-37

[BPK] Badan Pemeriksa Keuangan. 2016. Laporan Hasil Pemeriksaan BPK RI Atas Laporan Keuangan Pemerintah Pusat Tahun 2015. Jakarta (ID): BPK RI

[IIA] The Institute of Internal Auditor. 2013. IIA Position Paper: The Three Lines of Defense in Effective Risk Management and Control. Diakses 24 Juni 2017, dari http://global.theiia.org

Indonesian Corruption Watch. 2017. Laporan Tahunan ICW 2016. Diakses 1 Agustus 2017, dari http://www.antikorupsi.org/

Lediastuti, D., dan U. Subandijo. 2014. Audit Forensik Terhadap Pengelolaan dan Pertanggungjawaban Keuangan Negara (Studi Kasus pada Badan Pemeriksa Keuangan RI). e-Journal 
Magister Akuntasi Trisakti Volume

1 No.1: 89-108

[Pemerintah RI] Pemerintah Republik Indonesia. 2008. Peraturan Pemerintah Republik Indonesia Nomor 60 Tahun 2008 tentang Sistem Pengendalian Intern Pemerintah. Sekretariat Negara, Jakarta. (ID)

[Pemerintah RI] Pemerintah Republik Indonesia. 2010. Peraturan Pemerintah Republik Indonesia Nomor 53 Tahun 2010 tentang Disiplin Pegawai Negeri Sipil. Sekretariat Negara, Jakarta. (ID)

Permana, BA., HD. Perdana., dan L. Kurniasih. 2017. Determinant of Fraud in Government Agency: Empirical Study At The Finance And Development Supervisory Agency (BPKP) Of Jakarta Representative Office. Asia Pasific Fraud Journal Volume 2 No.1: 93108. doi:10.21532/apfj.001.17.02.01.08

Puspasari, N, dan E. Suwardi. 2012. Pengaruh Moralitas Individu dan Pengendalian Internal Terhadap Kecenderungan Kecurangan Akuntansi: Studi Eksperimen pada Konteks Pemerintahan Daerah. Simposium Nasional Akuntansi 15 Banjarmasin, Indonesia.

Rae, K., dan N. Subramaniam. 2008. Quality of Internal Control Procedures: Antecedents and Moderating Effect on Organisational Justice and Employee Fraud. Managerial Auditing Journal Volume 23 No.2: 104-124. doi: 10.1108/ 02686900810839820

Saaty, TL. 1993. Pengambilan Keputusan Bagi Para Pemimpin. Seri
Manajemen No. 134. Alih Bahasa Liana Setiono. Penerbit PT Pustaka Binaman Pressindo, Jakarta. (ID)

Subagio. 2016. Identify Main Factors That Influence Corruption And Suggest How To Eradicate The Corruption Problem In Indonesia. Asia Pasific Fraud Journal Volume 1 No.1: 37-48. doi: 10.21532/apfj.001.16.01.01.03

Suherman. 2017. Pola Mutasi, Reward \& Punishment vs Fraud. Artikel DJKN. Diakses 15 Juli 2017, dari https://www.djkn.kemenkeu.go.id/a $\mathrm{rtikel/baca/12542/Pola-Mutasi-}$

Reward-Punishment-vs-Fraud.html Surjandari, DA., dan I. Martaningtyas. 2015. An Empirical Study: The Effect of Performance Incentives, Internal Control System, Organizational Culture, on Fraud of Indonesia Government Officer. Mediterranian Journal of Social Sciences Volume 6 No.5: 7176.doi:

10.5901/mjss.2015.v6n5s5p71

Transparancy International. Corruption Perception Index 2016. Diakses 7 Juli 2017. Tersedia pada www.transparency.org

Wicaksono, AP., dan D. Urumsah. 2016. Factors Influencing Employees To Commit Fraud In Workplace Empirical Study In Indonesian Hospitals. Asia Pasific Fraud Journal Volume 1 No.1: 1-18.doi: 10.21532/apfj.001.16.01.01.01

Wiranta, DNS. 2015. Transformasi Birokrasi: Cara untuk Penguatan Etika dan Integritas dalam Pencegahan Korupsi. Jurnal Lingkar Widyaiswara Volume 2 No. 4: 44-71 